\title{
HLA Alleles in Anti-Endothelial Cell Antibody Positive Indian SLE Patients
}

\author{
U. Shankarkumar, V. D. Pradhan, M. Patwardhan, A.Pawar, A.Almeida and K Ghosh \\ National Institute of Immunohaematology, Indian Council of Medical Research, $13^{\text {th }}$ floor, \\ King Edward Memorial Hospital, Parel, Mumbai 400 012, Maharashtra, India
}

KEYWORDS Anti-endothelial Cell Antibodies (AECA). Systemic Lupus Erythematosus (SLE). Human Leukocyte Antigen (HLA)

\begin{abstract}
Anti-endothelial cell antibodies (AECA) are heterogeneous group of antibodies against a variety of antigenic determinants of endothelial cells (EC). AECA plays an immunopathogenic role in triggering EC activation leading to vascular damage. The presence and the strength of AECA have been found to correlate with disease activity in various systemic vasculitic diseases like systemic lupus erythematosus. To assess the involvement of HLA alleles in AECA production, 45 clinically and histopathologically proven cases of class IV lupus nephritis were studied for their HLA A and HLA B alleles by standard NIH microlymphocytotoxicity assay. All patients fulfilled ARA classification criteria for SLE. AECA were detected by indirect immunofluorescence using cultured human umbilical vein endothelial cells (HUVEC). Forty percent of the SLE patients possessed the AECA antibodies. The HLA alleles A9 (24) (OR=2.90, $\mathrm{EF}=0.29, \mathrm{p}$ value 0.08$)$ and $\mathrm{B} 21(\mathrm{OR}=74, \mathrm{EF}=0.11$, p value 0.038$)$ were significantly increased while HLA A1 $(\mathrm{OR}=0.27, \mathrm{PF}=0.35, \mathrm{p}$ value 0.039$)$ and $\mathrm{B} 40(\mathrm{OR}=0.29, \mathrm{PF}=0.25, \mathrm{p}$ value 0.076$)$ were significantly reduced among AECA positive SLE patients when compared with AECA Negative patients. Further two-locus haplotype analysis revealed that A19-B35, A3-B21, and A28-B21 were observed with significant T value among AECA positive patients. The common clinical symptoms among the AECA positive patients observed were lupus nephritis (84\%), involvement of skin (22\%), involvement of joints (17\%) and CNS as well as hematological involvement (11\%). Our findings suggest that immunogenetic mechanism may be involved in AECA antibody production leading to the immunopathogeneis in a subset of SLE patients.
\end{abstract}

\section{INTRODUCTION}

Circulating autoantibodies that bind to human endothelial cells cultured in vitro have been detected in a variety of autoimmune diseases (Moroni et al. 1996). Anti-endothelial cell antibodies (AECA) are a heterogeneous group of antibodies directed against a variety of antigenic determinants of endothelial cells (ECs) in these autoimmune disorders, which share a varying degree of vessel wall damage. Some of the target autoantigens of AECA are yet to be ascertained. The mechanism through which AECA potentiates EC activates apoptosis and vessel wall damage is to be explored (Moroni et al. 1996). Further reports (Meroni et al. 2005; Constans et al. 2003), show increasing evidence that AECA might have pathogenic role in

Address for correspondence:

Dr. U.Shankarkumar,

Scientist "D" HLA department,

National Institute of Immunohaematology,

Indian Council of Medical Research,

$13^{\text {th }}$ floor, King Edward Memorial Hospital,

Parel, Mumbai 400 012, Maharashtra, India

Fax: 91-22-24138521

E-mail: shankar2kumar@rediffmail.com inducing autoimmune vascular disease. AECA has been found to be associated with various autoimmune disorders mainly in the active stage of diseases like systemic lupus erythematosus (SLE), scleroderma, Wegener's granulomatosus (WG), mixed connective tissue disorders (MCTD), Sjogren's syndrome, rheumatoid arthritis (RA), systemic vasculitis, lupus nephritis (LN), Kawasaki disease, progressive systemic sclerosis (PSS) etc (Meroni et al. 2005). Therefore the measurement of AECA may improve understanding the etiopathogenetsis of various autoimmune disorders.

Systemic lupus erythematosus (SLE) is a chronic autoimmune disease characterized by the production of a broad spectrum of autoantibodies and it has been suggested that several autoantibody specificites play an important role in the pathogenesis of this disease. The proportion of AECA positivity ranges from $16 \%$ to $83 \%$ in SLE (D' Cruz et al. 1991) In patients with acute lupus nephritis AECA was found to be associated with histological evidence of active renal injury leading to endothelial cell dysfunction supportive of pathogenic involvement in Lupus Nephritis (LN). Further 365 of patients with 
LN had IgG-AECA correlating with high titer of anti-ds DNA antibodies (D' Cruz et al. 1999).

Earlier studies have shown that genetic factors are involved in the pathogenesis of SLE. Multiple loci within the major histocompatibility complex (MHC) have been implicated in SLE susceptibility. HLA Class II alleles complement components, tumor necrosis factor (TNF) loci, have been shown to be involved. HLA association studies from Indian SLE patients are considerably limited (Mehra et al. 1993). A significant increase in HLA A1, A2, B27, DRB1*03, DQB 1*0302 and DQB1*0601 were observed among SLE patients from western India (Shankarkumar et al. 2003).

\section{MATERIAL AND METHODS}

A total of forty-five clinically and histopathologically proven SLE patients fulfilling the revised ARA classification were studied. The details of clinical, histopathological and laboratory findings were also recorded. The study was carried out after obtaining the requisite Ethics Committee permission. SLE disease activity index was assessed by the SLE disease activity index (SLEDAI) (Zhang et al. 1999; Westphal et al. 1994). All the patients were in active stage of disease and were untreated at the time of presentation. Patients had no history of taking any drugs like hydralazine, propylthiouracil etc. The HLAA and HLA B locus antigens were identified by a National Institute of Health two-stage microlymphocytotoxicity assay using indigenous and commercial HLA antisera. The allele and haplotype frequencies, odds ratio, probability value and chisquare were estimated using our database and computer program. The $\mathrm{p}$ value was corrected by the Bonferoni inequality method.

Isolation and culture of endothelial cells (HUVEC) was done as follows. ECs were isolated from sterile human umbilical cords of blood group) positive foetus by collagenase $(0.2 \% \mathrm{v} / \mathrm{v})$ digestion of interior walls of umbilical veins by passing an umbilical catheter through it (Bombardier et al. 1992). The cells were grown in tissue culture medium IMDM (Sigma, USA), supplemented with 10\% FCS (Gibco) supplemented with $2 \mathrm{ml}$ glutamine, $100 \mathrm{U}$ penicillin/ $\mathrm{ml}$ and $100 \mathrm{mg}$ of streptomycin/ml. The culture plates were incubated at $37^{\circ} \mathrm{C}$ under $5 \% \mathrm{CO}_{2}$ atmosphere. The cells were supplemented with culture medium at two-day intervals and morphology was confirmed by phase contrast light microscopy showing the typical cobblestone monolayer appearance of endothelial cells. The confluent cells after second passage were used after giving two washes with PBS (0.01 M, pH 7.2) and adjusting the cell count to $1 \times 10^{6} / \mathrm{ml}$. Homogenous population of actively growing ECs (>90\% von Willibrand factor antigen positive) on second passage was obtained, which was detected by using anti-vWF monoclonal antibody (Dako, Denmark) by indirect immunofluorescence test (IIF).

Detection of AECA was performed by IIF test using HUVEC (Perry et al. 1993). HUVEC cells $\left(1 \mathrm{X} 10^{5}\right)$ were diluted in PBS $(0.01 \mathrm{M}, \mathrm{pH}$ 7.2). The ECs were used to prepare a cytospun substrate using Hitachi Universal 16A cytocentrifuge and the test serum diluted 1:20 was allowed to react for 45 minutes at $4^{\circ} \mathrm{C}$. Slides were further probed with FITC tagged polyvalent (IgG, IgM, IgA) anti-human globulin serum (Sigma, USA) using a fluorescent microscope (Nikon, Optiphot II) and microphotography was done using an automated photography system. (Nikon, AFX IIA, Japan). The positive results were interpreted in terms of titers i.e., test sera giving positivity at its highest dilution. Immunoglobulin subclass of AECA was identified in all AECA positive sera using FITC tagged IgG, IgM and IgA monovalent anti-human globulin serum. (Sigma, USA).

\section{RESULTS}

An increase in frequencies HLAA9 (24), A19 (31), B7, B15 (62), B21, B22, B27 were observed among the AECA positive patients (Table 1). Further a decrease in the frequencies of HLAA1, A3, A28, B5, B17, B40 were observed among the AECA positive patients. The HLA alleles A9 (24) $(\mathrm{OR}=2.90, \mathrm{EF}=0.29, \mathrm{p}$ value 0.08$)$ and $\mathrm{B} 21(\mathrm{OR}=74$, $\mathrm{EF}=0.11, \mathrm{p}$ value 0.038 ) were significantly increased while HLA A1 $(\mathrm{OR}=0.27, \mathrm{PF}=0.35, \mathrm{p}$ value 0.039$)$ and $\mathrm{B} 40(\mathrm{OR}=0.29, \mathrm{PF}=0.25$, $\mathrm{p}$ value 0.076 ) were significantly reduced among AECA positive SLE patients when compared with AECA Negative patients after Bonferoni's correction. Further two-locus haplotype analysis revealed that A19-B35, A3-B21, and A28-B21 were observed with significant $T$ value among AECA positive patients. (Table 2) The common clinical symptoms among the AECA positive patients observed were lupus nephritis (84\%), involvement of skin (22\%), involvement of joints (17\%) 
HLA ALLELES IN ANTI-ENDOTHELIAL CELL ANTIBODY POSITIVE INDIAN SLE PATIENTS

Table:1 HLA association in AECA positive SLE patients from Mumbai, India

\begin{tabular}{|c|c|c|c|c|c|c|c|}
\hline$H L A$ & $\begin{array}{c}A E C A+v e \\
N=18\end{array}$ & $\begin{array}{c}A E C A-v e \\
N=37\end{array}$ & $O R$ & $K i 2$ & $E F$ & $P F$ & $P$ value \\
\hline & $\mathrm{n}(\mathrm{AF} \%)$ & $\mathrm{n}(\mathrm{AF} \%)$ & & & & & \\
\hline A 1 & $4(11.11)$ & $19(25.67)$ & 0.27 & 4.05 & & 0.35 & $0.039 * *$ \\
\hline A 2 & $9(25.00)$ & $17(22.97)$ & 1.18 & 0.08 & & & \\
\hline A 3 & $4(11.11)$ & $9(12.16)$ & 0.89 & 0.01 & & 0.02 & \\
\hline A9 & $8(22.22)$ & $8(10.81)$ & 2.90 & 3.08 & 0.29 & & $0.08 * *$ \\
\hline A 11 & $2(5.55)$ & $4(5.40)$ & 1.03 & 0.02 & & & \\
\hline A 19 & $7(19.44)$ & $8(10.81)$ & 2.31 & 1.89 & 0.21 & & \\
\hline A 28 & $2(5.55)$ & $5(6.75)$ & 0.80 & 0.02 & & 0.01 & \\
\hline A31 & $2(5.55)$ & $1(1.35)$ & 4.50 & 1.85 & 0.08 & & \\
\hline B5 & $4(11.11)$ & $14(18.91)$ & 0.47 & 0.50 & & 0.18 & \\
\hline B7 & $5(13.88$ & $4(5.40)$ & 3.17 & 3.03 & 0.18 & & \\
\hline B12 & $4(11.11)$ & $4(5.40)$ & 2.54 & 1.26 & 0.13 & & \\
\hline B 15 & $1(2.77)$ & $0(0.00)$ & 37.00 & & 0.05 & & \\
\hline B 17 & $2(5.55)$ & $7(9.45)$ & 0.54 & 0.62 & & 0.06 & \\
\hline B 18 & $1(2.77)$ & $1(1.35)$ & 2.12 & 2.09 & 0.03 & & \\
\hline B21 & $2(5.55)$ & $0(0.00)$ & 74.00 & & 0.11 & & $0.038 * *$ \\
\hline B22 & $3(8.33)$ & $3(4.05)$ & 2.27 & 2.23 & 0.09 & & \\
\hline B27 & $3(8.33)$ & $3(4.05)$ & 2.27 & 2.23 & 0.08 & & \\
\hline B35 & $6(16.66)$ & $9(12.16)$ & 1.56 & 1.56 & & & \\
\hline B 40 & $3(8.33)$ & $15(20.27)$ & 0.29 & 0.33 & & 0.25 & $0.076 * *$ \\
\hline B53 & $1(2.77)$ & $2(2.70)$ & 1.03 & 1.22 & & & \\
\hline B55 & $1(2.77)$ & $1(1.35)$ & 2.12 & 2.09 & 0.03 & & \\
\hline B56 & $1(2.77)$ & $1(1.35)$ & 2.12 & 2.09 & 0.03 & & \\
\hline B62 & $1(2.77)$ & $0(0.00)$ & 37.00 & & 0.05 & & \\
\hline
\end{tabular}

$\mathrm{n}=$ Number positive, $\mathrm{Ki} 2=$ Chisquare with Yates correction, $\mathrm{AF}=(\%)$ Allele frequency percentage, $\mathrm{OR}=\mathrm{Odds}$ ratio $\mathrm{EF}=$ Etiological fraction, $\mathrm{PF}=$ Preventive fraction, **Significant $\mathrm{P}$ value

Table 2: Significant Two-Locus Haplotypes identified among SLE patients.

\begin{tabular}{ccccc}
\hline Haplotypes & $H F(\%)$ & $D(\%)$ & $K i 2$ & $T$ val \\
\hline AECA +ve & & & & \\
A3-B21 & 5.72 & 5.04 & 11.09 & 2.19 \\
A19-B27 & 8.71 & 6.81 & 8.44 & 2.80 \\
A28-B21 & 5.72 & 5.39 & 26.59 & 2.19 \\
A19-B35 & 10.89 & 6.88 & 4.22 & 2.36 \\
AECA -ve & & & & \\
A2-B17 & 5.92 & 3.73 & 4.46 & 2.43 \\
A3-B21 & 2.78 & 2.43 & 9.77 & 2.08 \\
A9-B40 & 6.76 & 3.94 & 3.92 & 2.11 \\
A19-B27 & 4.71 & 3.67 & 8.64 & 2.49 \\
A19-B35 & 6.96 & 4.40 & 5.52 & 2.39 \\
A11-B53 & 2.78 & 2.62 & 25.41 & 2.09 \\
A28-B21 & 2.78 & 2.60 & 22.12 & 2.09 \\
\hline
\end{tabular}

HF $(\%)=$ Haplotype frequency in Percentage

LD $(\%)=$ Linkage disequlibrium in Percentage

Ki2 $=$ Chi-square with Yates correction

$\mathrm{T}$ val $=>2$ is significant

and CNS as well as hematological involvement (11\%).

\section{DISCUSSION}

Anti-endothelial cell antibodies (AECA) are a heterogeneous group of autoantibodies detected in number of systemic autoimmune diseases. Their occurrence has been well correlated with both disease activity and vessel wall inflammation. AECA directed to microvascular and macrovascular Endothelial cells (ECs) found to have a potential role in the development of vasculopathy or thrombosis in vascular injuries. AECA are also found to activate microvascular and macrovascular ECs via elevated expression of thrombomodulin, IL6 and adhesion molecules (P-selectin, E-selectin, VCAM-1), followed by enhanced monocytes activation to EC or induction of apoptosis (Ali et al. 1989; Hatfield et al. 1987).

The proportion of AECA positivity ranges from $16 \%$ to $85 \%$ in SLE$^{3}$. Perry et al (1993), had reported $73 \%$ patients with $\mathrm{LN}$ in acute stage of disease with AECA positivity as compared with $44 \%$ incidence in SLE patients without evidence 
of nephritis (Youinou et al. 1995). D' Cruz et al (1999), had reported $81 \%$ AECA among LN patients and had found higher levels of AECA than those SLE cases without renal involvement ${ }^{2}$. Zhang et al (1999), had reported an incidence of $36.2 \%$ AECA among LN patients ${ }^{5}$. The over all incidence of AECA positivity was $38.4 \%$ with a slightly higher incidence of $39.6 \%$ among LN patients (Pradhan et al. 2002). Literature review shows that HLA allele involvements in AECA antibody production have been not very well understood and our findings could be the first attempt to explore the role of HLA in AECA antibody production. This is the first report to our knowledge in the role of AECA production in SLE associated with SLE.

Understanding how the HLA allele restriction involved in endothelial response to inflammation will give a better understanding of immunopathogenesis in vasculitis related disorders. In conclusion this study has demonstrated the immunogenetics has a role in the presence of AECA in SLE patients.

\section{REFERENCES}

Ali US, Dalvi RB, Merchant RH, Mehta KP, Chablani AT, Badakere SS, Bhatia HM. 1989. Systemic lupus erythematosus in Indian children. Ind Ped, 26: 868873.

Bombardier C, Gladman DD, Urowit MB, Caron D, Chang CH. 1992. Derivation of SLEDAI: A disease activity index for lupus patients. The committee on prognosis studies in SLE. Arch Rheum, 35: 630640.

Constans J, Dupuy R, Blann AD, Resplandy F, Seigneur M, Renard M, Longy-Bousier M, Schaererbeke T, Guenin V, Biosseau MR, Conri C. 2003. Antiendothelial cell autoantibodies and soluble markers of endothelial cell dysfunction in systemic lupus erythematosus. J Rheumatol, 30: 1963-1966.

D' Cruz D, Houssian FA, Ramirez G, Baguley E, McCulcheon J, Vainna J, Haga HJ, Swana GT, Khamashta MA, Taylor JC, Davies DR, Hughes GRN. 1991. Anti-endothelial cell antibodies in Systemic lupus erythematosus: a potential marker for nephritis and vasculitis. Clin Exp Immunol, 85: 254-261.

D' Cruz DP, Keser G, Direskeneli H, Khamashta MA, Huges GR. 1999. Anti-endothelial cell antibodies in systemic vasculitis and systemic lupus erythematosus (SLE); effects of heat inactivation on binding and specificity. Clin Exp Immunol, 115: 567-570.

Hatfield M, Evans M, Suenaga R, Hassanein KM, Abdou Nl. 1987. Anti-idiotypic antibody against anti-DNA in sera of laboratory personnel exposed to lupus sera or nucleic acids. Clin Exp Immunol, 70: 26-34.

Mehra, NK, Pande I, Taneja V, Uppal SS, Saxena SP, Kumar A, Malviya AN.1993. Major histocompatibility complex genes and susceptibility to systemic lupus erythematosus in Northern India. Lupus, 2: 313-14.

Meroni P, Ronda N, Raschi E, Borghi M. 2005. Humoral autoimmunity against endothelium: theory or reality? Trends in Immunology, 26: 275-281.

Moroni PL, D' Cruz D, Khamashta MA, Youinou P, Hughes GR. 1996. Anti-endothelial cell antibodies: Only for scientists or for clinicians too ? Clin. Exp Immunol, 104: 199- 202.

Perry GJ, Elston T, Khouri NA, Chan TM, Cameron JS. 1993. Anti-endothelial cell antibodies in lupus: correlation with renal injury and circulating markers of endothelial damage. $Q J$ Med, 86: 727-734.

Pradhan VD, Badakere SS, Bichile LS, Dolas MP. 2002. Antibodies to Ro/SS-A and La/SS-B in systemic lupus erythematosus and other autoimmune disorders. $J$. Assoc Physicians India, 50: 759-761.

Shankarkumar U, Ghosh K, Badakere SS, Mohanty D. 2003. HLA DRB $1 * 03$ and DQB $1 * 0302$ association in a subset of patients severely affected with systemic lupus erythematosis from Western India. Ann Rheum. Dis, 62: 92-93.

Westphal JR, Boerbooms AM, Schalkwijk CJ, Kwast H, Weijert MD, Jacobs C, Vierwinden G, Ruiter DJ, Van de Putte LB, De Waal RM. 1994. Anti- endothelial cell antibodies in sera of patients with autoimmune diseases: Comparison between ELISA and FACS analysis. Clin Exp Immunol, 96: 444-449

Youinou P, Meroni PL, Khamashta MA, Shoenfield Y. 1995. A need for standardization of the anti endothelial cell antibody test. Immunology Today, 16: 363-365.

Zhang Y, Geng H, Zhao M, Zou W, Zheng X, Wang H. 1999. The significance of anti-endothelial cell antibodies in patients with lupus nephritis and immunoblotting analysis of the target components. Chin Med J (Engl), 112: 597-602. 